\title{
RYZYKO W ZARZĄDZANIU PROJEKTAMI - STUDIUM PRZYPADKU
}

\author{
Artur Opara 1 \\ x-kom Sp. z o.o. \\ Biuro Zarządzania Projektami
}

\begin{abstract}
Streszczenie: Celem artykułu jest przybliżenie metody identyfikacji ryzyk dla projektu kampanii marketingowej. Struktura podziału ryzyka stanowi jeden z podstawowych dokumentów zarządzania ryzykiem, jednocześnie niejednokrotnie najczęściej wykorzystywanych podczas całego projektu. Identyfikacja najważniejszych obszarów ryzyk w projekcie wpływa na zarządzanie ryzykiem podczas całego przebiegu projektu. Nieuwzględnienie niektórych istotnych obszarów może wpłynąć na elementy trójkąta projektowego, co daje możliwość znaczącego wpływu na sukces projektu. Przedstawione studium przypadku pokazuje obszary, które zostały zidentyfikowane w prowadzonym projekcie marketingowym w przedsiębiorstwie.
\end{abstract}

Słowa kluczowe: ryzyko, struktura podziału ryzyka, zarządzanie ryzykiem

DOI: $10.17512 /$ znpcz.2020.3.01

\section{Wprowadzenie}

Od setek lat mamy do czynienia z zarządzaniem projektami. Niezależnie od czasów każdemu projektowi towarzyszy niepewność i nieprzewidywalność w jego realizacji. Zakres koncepcji zarządzania projektami jest bardzo rozległy. Jest on określony przez prace przygotowawczo-wdrożeniowe, a więc organizację i planowanie przedsięwzięć, analizę efektywności, wdrożenie projektu, jak również przez metodologię prac badawczo-projektowych. W pierwszym przypadku zarządzanie projektami to swoista pragmatyka menedżerska, która związana jest $\mathrm{z}$ administrowaniem procesów projektowo-realizacyjnych, $\mathrm{w}$ drugim przypadku istota zarządzania projektami jest zorientowana na kierownictwo w celu merytorycznego rozwiązywania zadań projektowych (Stabryła 2006, s. 31).

Ustrukturyzowanie metod zarządzania wpływa na jakość projektu, a zdobyte doświadczenie rzutuje na prawdopodobieństwo powodzenia inicjatywy. W całej niepewności zarządzania projektami jedno z największych wyzwań stanowi zarządzanie ryzykiem. Autor w artykule przedstawia sytuacje, które mogą wystąpić i wpłynąć pozytywnie lub negatywnie na projekt. Celem artykułu jest przybliżenie zagadnienia identyfikacji ryzyka $\mathrm{z}$ wykorzystaniem struktury podziału ryzyk na przykładzie projektu kampanii marketingowej.

\footnotetext{
${ }^{1}$ Artur Opara, mgr inż., artur@opara.net, ORCID: 0000-0002-5635-5762
} 


\section{Zarządzanie projektami}

Zarządzanie projektami to wykorzystanie wiedzy, umiejętności, narzędzi i technik, aby osiągnąc zakładane cele projektowe. Instytut Zarządzania Projektem definiuje zarządzanie projektami jako „zastosowanie wiedzy, umiejętności, narzędzi $\mathrm{i}$ technik działania projektu w celu zaspokojenia lub nawet przekroczenia potrzeb i oczekiwań udziałowców związanych z tym projektem" (Mingus 2002, s. 21). Kontynuując, można powiedzieć, iż „pojęcie zarządzania projektami stosuje się niekiedy, opisując nastawienie organizacji do zarządzania działalnością operacyjną. Podejście to, które należałoby raczej nazwać zarządzaniem przez projekty, polega na traktowaniu wielu aspektów działalności operacyjnej w taki sposób, w jaki traktuje się projekty [...]. Poznanie zasad zarządzania projektami jest podstawą właściwego stosowania zarządzania przez projekty" (Spałek 2004, s. 20).

Zarządzanie odbywa się poprzez zbiory grup procesów, takich jak: inicjowanie, planowanie, wykonywanie, monitorowanie i kontrolowanie (,istota kontroli zawsze sprowadza się do czynności ustalania stanu istniejącego, porównywania go z odpowiednimi wzorcami, dokonywania oceny i formułowania wniosków pokontrolnych, czyli inaczej mówiąc, jest to działanie polegające na badaniu istniejącego stanu rzeczy, zestawianiu faktów z tym, co być powinno, i wyciąganiu wniosków. Tak więc punktem wyjścia do określenia pojęcia kontroli - w ujęciu prakseologicznym, w ujęciu nauk o organizacji i zarządzaniu - są dwa podstawowe elementy działalności ludzkiej:

- wyznaczenia - np. normy prawne, normy etyczne, procedury, tzw. dobre praktyki wskazują, jaka powinna być działalność, określają stan obowiązujący, będąc wzorcami działalności rzeczywistej, stanowią zarazem kryterium jej oceny;

- wykonania - w przeciwieństwie do wyznaczeń to faktyczne działanie poszczególnych osób lub zespołów, mogące stanowić całkowitą lub częściową realizację wyznaczeń, mogą też być częściowo lub całkowicie niezgodne z wyznaczeniami; zadaniem kontroli jest więc porównywanie wykonań z wyznaczeniami w celu stwierdzenia ich zgodności oraz wyjaśnianie przyczyn stwierdzonych różnic między wykonaniami a wyznaczeniami” (Kałużny 2008, s. 21))

oraz zamykanie (PMI 2013, s. 5-6). Zarządzanie projektem należy uznać zatem za proces polegający na zapewnieniu efektywnego przebiegu składowych cyklu życia projektu, począwszy od jego inicjacji, przez planowanie, realizację, aż po zamknięcie (Koźmiński, Piotrowski 2002, s. 486). Zatem można uznać, że projekty są rezultatem projektowania, czyli procesu polegającego na inicjacyjnym wdrażaniu, decydowaniu, ustalaniu zasad i reguł postępowania, które wskazują drogę do realizacji określonego działania.

W literaturze przedmiotu definicje zarządzania projektami wskazują na konieczność zaplanowanego działania, które wymaga podjęcia w znacznym stopniu pracy służącej realizacji wszystkich funkcji zarządzania, a w szczególności procesów zarządzania i kontroli (Lock 2009, s. 11-40, 124; Stabryła 2011, s. 10; Pawlak 2006, s. 27-32; Süß 2001, s. 1-7; Jones 2009, s. 87-96). Sposób wykorzystania odpowiednich instrumentów zarządzania projektami przedstawia myślenie oparte na tzw. trój- 
kącie zarządzania projektami (Patzak, Ratty 2009, s. 219). Jego zakres tworzą jakość, czas i koszty realizacji, które stanowią najistotniejsze cechy podlegające monitorowaniu oraz analizie. Bardzo często również mają one istotny wpływ na ocenę projektów w ramach kryteriów efektywności i skuteczności. Pośród następnych bardzo istotnych elementów wpływających na realizację projektów należy wyróżnić także ludzkie (Strużyna 2010, s. 409) oraz wiedzę, jak również ryzyka towarzyszące każdej działalności.

W organizacjach zorientowanych na projekty kierownicy projektów raportują swoje działania do prezesów organizacji, członków zarządu lub kierownictwa zarządzającego portfelem projektów. Kierownik projektu w takiej strukturze ma pełną władzę nad projektem, podczas gdy pozostałe działy sprawują funkcje pomocnicze. Ma on możliwość powoływania zespołów projektowych, przydzielania zasobów i koncentrowania się na pracy nad projektem. Członkowie zespołu przypisani do projektu podlegają bezpośrednio kierownikowi projektu, a ich wyłączna odpowiedzialność obejmuje działania specyficzne dla projektu.

Biuro zarządzania projektami (PMO - project management office) zazwyczaj nadzoruje zarządzanie programami i projektami w organizacji. Najczęstszym zadaniem jest ustanowienie i utrzymanie standardów i procedur zarządzania projektami oraz zasobami przypisanymi do projektów w PMO. Kluczowym celem biura projektów jest wsparcie dla kierowników projektów w celu zwiększenia prawdopodobieństwa ich pomyślnego zakończenia. Do zadań należy również utrzymywanie dokumentacji projektowej do wykorzystania w przyszłości (Heldman 2018, s. 7-17).

Zarządzanie projektami jest praktykowane bez względu na wielkość projektu. W przypadku małych przedsięwzięć dostarcza modeli postępowania dla przyszłych projektów, w tym tych o większym poziomie skomplikowania. Umożliwia ciągłe doskonalenie procesu (Rowe 2020, s. 16).

\section{Zarządzanie ryzykiem}

Ryzyko to jedno lub wiele zdarzeń, które w przypadku wystąpienia mogą mieć wpływ na powodzenie projektu. Miarą ryzyka jest iloczyn prawdopodobieństwa wystąpienia danego ryzyka oraz jego wpływu na cele projektu. Zarządzanie ryzykiem (Hahn 2020, s. 13-46) to stosowanie procedur związanych z zadaniami identyfikacji ryzyka, jego oceny oraz planowania i wdrażania reakcji na nie. Proces zarządzania ryzykiem powinien być iteracyjny wraz z pozyskiwaniem dodatkowych informacji (Axelos 2014, s. 81-83).

Celem zarządzania ryzykiem w projektach jest dostarczenie organizacji pewności, że możliwe są do osiągnięcia cele projektowe oraz zidentyfikowanie i wykorzystanie szans na uzyskanie lepszych wyników. Zarządzanie ryzykiem na podstawie posiadanej wiedzy i jej przeglądów dodaje pewności w lepszym podejmowaniu decyzji. W obliczu niepewności alokacja zasobów i wsparcie w zarządzaniu redukuje narażenie na negatywne skutki wystąpienia ryzyka. Promuje rozważne podejmowanie ryzyka w momencie, gdy może przynieść to organizacji wymierne korzyści (Hillson (ed.) 
2016, s. 75). Spotykane strategie zarządzania ryzykiem to (Hahn 2020, s. 13-46): ignorowanie istnienia ryzyka, transfer ryzyka - ubezpieczenie się od ryzyka, redukcja ryzyka przez stosowanie zabezpieczeń, która wymaga oszacowania wielkości ryzyka.

\section{Identyfikacja ryzyk}

Celem identyfikacji ryzyka jest minimalizowanie nieznanego. Ryzyka mogą wystąpić jednokrotnie, wielokrotnie lub nie wystąpić nigdy. Mogą zaistnieć przy określonym warunku lub kombinacji wielu warunków. Jeden warunek może powodować wiele konsekwencji lub wiele zdarzeń i warunków może spowodować jedną konkretną konsekwencję. Każde ryzyko powinno być zarejestrowane, przeanalizowane, opisane i winno posiadać plan działania w przypadku jego wystąpienia (IIBA 2015, s. 329).

Struktura podziału ryzyka (RBS - risk breakdown structure) używana w obecnej formie, którą przedstawił w 2002 roku David Hillson, służy do lepszego zrozumienia i rozpoznania powiązanych w logiczne i naturalne grupy ryzyk. Przy tworzeniu hierarchii bazujemy na podstawie doświadczeń organizacji lub na podstawie wątpliwości, które mogą towarzyszyć projektowi. Stworzona struktura służy następnie do identyfikacji, analizy i raportowania ryzyk w danych obszarach. Struktura podziału ryzyk pozwala na dogłębną analizę zagrożeń z różnych perspektyw, dlatego wprowadzenie jej jest silnie uzasadnione w organizacji lub projektach, które nie miały wcześniej wprowadzonego takiego narzędzia. Struktura jako element prezentacji podkreśla znaczące źródła ryzyk i może pokazać, jak poszczególne źródła wpływają na ryzyka w różnych obszarach. Dla danego typu projektu możemy wykazać specyficzne i nieodłączne obszary ryzyka. Obszary, w których zostały zidentyfikowane większe ilości ryzyk, są potencjalnie większym źródłem ryzyka dla danego projektu. RBS służy do wyjaśniania i sortowania informacji o ryzykach, a nie do tworzenia dużej ilości nowych danych, co wpływa na jego ogromną przydatność i skuteczność. W przypadku gdy organizacja ma osobne repozytoria dotyczące ryzyka, pozwala również na skupienie swoich badań na konkretnych źródłach tych ryzyk (Pritchard 2015, s. 167-174).

\section{Studium przypadku zarządzania ryzkiem w projekcie}

W tej części publikacji przeanalizowany zostanie przykład zarządzania projektem w przedsiębiorstwie. Zgodnie z przyjętą tematyką, analiza będzie przeprowadzona szczególnie w odniesieniu do ryzyka towarzyszącego projektowi.

Firma jako jeden z czołowych sprzedawców sprzętu komputerowego w Polsce prowadzi wiele akcji marketingowych. W przedmiotowym przypadku kampania wychodziła poza dotychczasowe działania, ze względu na dużą liczbę dostawców sprzętu, jak i kilkunastu partnerów handlowych uczestniczących w kampanii. W celu zwiększenia skuteczności zarządzania kampania została zdefiniowana jako projekt i była zarządzana zgodnie z kanonami zarządzania projektami obowiązującymi w PMO. Do identyfikacji ryzyk wykorzystano strukturę podziału ryzyka (RBS). Podczas tzw. burzy mózgów, czyli na zespołowym spotkaniu, zostały zdefiniowane i omówione ryzyka w projekcie. Spotkanie było prowadzone w formie wideokonferencji w kilku 
lokalizacjach i przy zaangażowaniu wielu działów w firmie. Celem było uzyskanie największej liczby osób mogących zidentyfikować obszary, w których mogą wystąpić potencjalne zagrożenia z rozbiciem ich na mniejsze części.

Po zidentyfikowaniu głównych obszarów potencjalnego ryzyka sprawdzano, czy można było dopisać kolejne podkategorie, czyli niższe poziomy, schodząc maksymalnie w dół, ale tylko do uzasadnionego poziomu, na którym ze względu na ich ilość ryzyko może być nadal zarządzane.

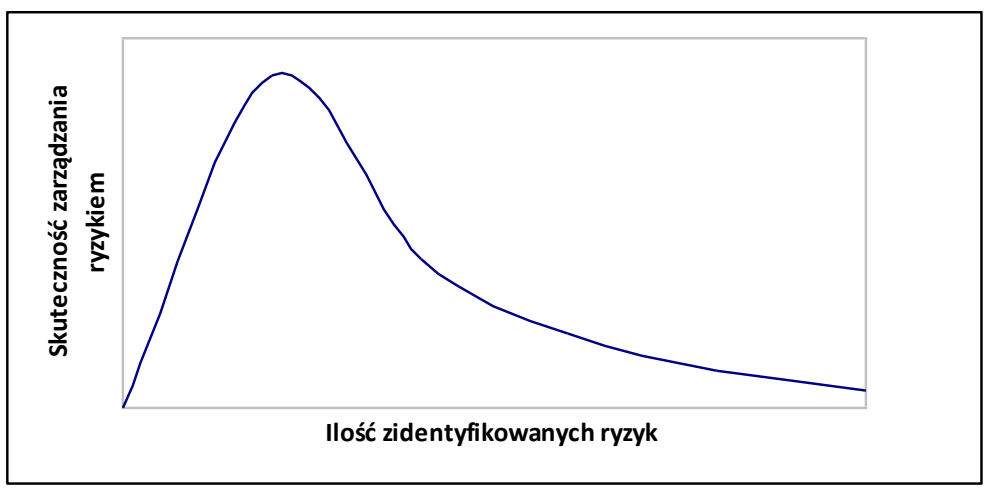

\section{Rysunek 1.Skuteczność zarządzania ryzykiem}

Źródło: Opracowanie własne

Na Rysunku 1 zobrazowano, jak ilość zidentyfikowanych ryzyk wpływa na skuteczność monitorowania i zarządzania ryzykiem. Prowadzi to do decyzji wyniesienia najistotniejszych obszarów do głównych kategorii i przejścia na zarządzanie kategorią wyższego rzędu w razie utraty kontroli nad zarządzaniem ryzykiem w projekcie.

W przypadku projektu należy zidentyfikować obszary dotyczące całej organizacji, aby nie można było pominąć kluczowych zasobów lub elementów, które mogą wpłynąć na sukces projektu. Na Rysunku 2 przedstawiono ryzyka zidentyfikowane, omówione i wyznaczone do monitorowania.

W głównych kategoriach zostały zdefiniowane następujące grupy ryzyk:

- Prawne - ze względu na wielostronne porozumienie należy uwzględnić czas na przygotowanie i podpisanie wszystkich umów.

- Budżet - negocjacje budżetów i zarządzanie budżetem na realizację poszczególnych zadań.

- Logistyka - ze względu na automatykę funkcjonującą w centrum dystrybucji będzie konieczna modyfikacja procesu pakowania poprzez dodanie ulotek do wybranych paczek, co również wpłynie na obsadę magazynu.

- Marketing - ze względu na charakter projektu najszersza identyfikacja ryzyk dotyczy marketingu; w szczególności wyróżnione zostały takie obszary jak szablony identyfikacji, przygotowanie marketingu przy wykorzystaniu zespołów własnych, marketing po stronie partnerów, ogólne działania marketingowe stosowane w pozostałych kampaniach oraz monitorowanie i raportowanie akcji. 
- Partnerzy - muszą zostać określone produkty Hero odpowiednio wcześniej przed startem kampanii oraz przygotowane procedury reklamacyjne obowiązujące u partnerów.

- Techniczne - przygotowanie zaplecza technicznego strony internetowej, strony akcji, testów wydajności, raportów obciążenia.

- Zasoby - eksperci w salonach i contact center muszą zostać odpowiednio wcześniej przeszkoleni i otrzymać wytyczne odnośnie procedur postępowania dla danej akcji.

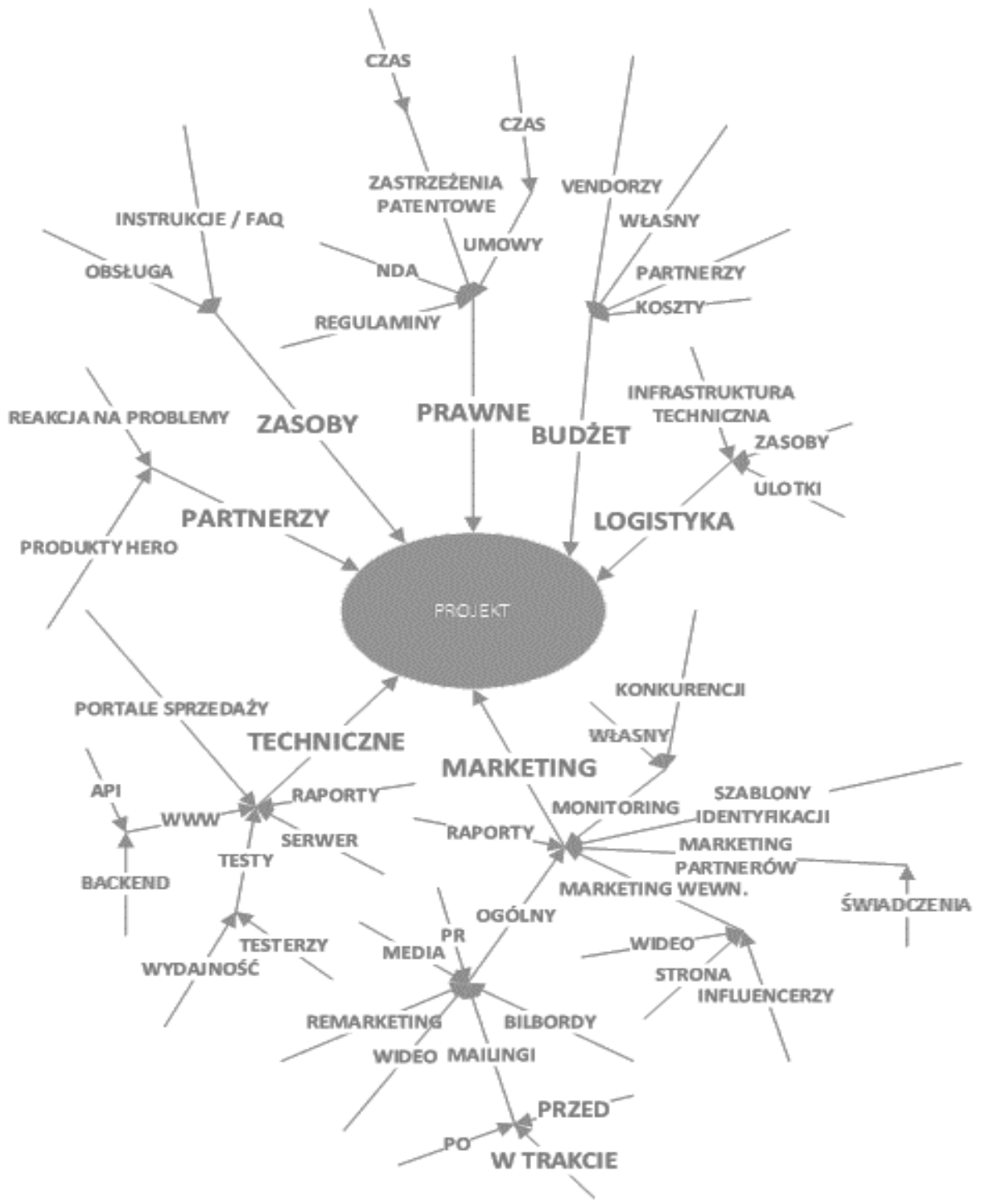

Rysunek 2. Struktura podziału ryzyk dla projektu

Źródło: Opracowanie własne 


\section{Korzyści z zastosowania podejścia do zarządzania ryzykiem}

Diagram struktury podziału ryzyk jest metodą wydobywania ryzyk, którą można wprowadzić niezależnie od wielkości projektu czy organizacji. Ze względu na prostą formę mogą ją wykorzystywać kierownicy projektów czy menedżerowie ryzyk z mniejszym stażem pracy przy projektach. Uczestnictwo zespołu podczas wydobywania ryzyk pozytywnie wpływa na członków i mogą zostać wskazani naturalni liderzy dla poszczególnych obszarów.

\section{Ograniczenia zarządzania ryzykiem}

Do każdego z ryzyk w przypadku opracowywania struktury podziału ryzyka można przypisywać prawdopodobieństwo wystąpienia oraz wpływ na projekt. Podczas identyfikacji, aby nie komplikować samego procesu, skupienie zostało skierowane tylko na samą identyfikację obszarów ryzyk.

\section{Podsumowanie}

Zarządzanie ryzykiem w projektach jest kluczowe w kontekście sukcesu projektu. Ze względu na niepewność towarzyszącą projektom zarządzanie ryzykiem w nich jest tak samo ważne jak kontrola budżetu czy harmonogramu prac. Już na etapie analizy i inicjacji projektu niezbędne jest zaplanowanie sposobu zarządzania ryzykiem. Następnie należy ustalić zasady i metody identyfikacji ryzyk oraz zaplanować działania i reakcje na wystąpienie ryzyka. Monitorowanie i kontrola ryzyka są istotne przez cały czas trwania projektu. Pomimo elementarnej wiedzy na temat kolejnych etapów zarządzania ryzykiem jest ono najczęściej ignorowanym procesem w projekcie i dokumentacja zarządzania ryzykiem jest jednym z ostatnich aktualizowanych dokumentów. Prowadzi to do wniosków, że jeśli ryzyko zarządzania w projekcie ma być nadzorowane i kontrolowane, to lepiej, aby oparło się ono chociaż na strukturze podziału ryzyk, która jest regularnie przeglądana i aktualizowana, niż na nienadzorowanych rozbudowanych tabelach z wagami i reakcjami na wystąpienie każdego szczegółowo opisanego ryzyka, które zostały opracowane wyłącznie na wstępnym etapie projektu i tylko na potrzeby dokumentacji. Zarządzanie projektem jest niebywale trudnym przedsięwzięciem wymagającym sumienności, konsekwencji i olbrzymiej determinacji na każdym etapie tego wielowymiarowego procesu, zarówno w skali krajowej, jak i międzynarodowej, a realizacja wszystkich zaplanowanych zadań świadczy o sukcesie menedżerskim, infrastrukturalnym oraz ludzkim.

\section{Literatura}

1. Axelos (2014), PRINCE2 ${ }^{\circledR}$ - Skuteczne zarzadzanie projektami, TSO The Stationery Office.

2. Hahn D. (2020), Risikomanagement, [w:] Risiko-Management in Kommunen. Handlungsorientierter Leitfaden für die kommunale Praxis, Springer Gabler, Wiesbaden.

3. Heldman K. (2018), Project Management JumpStart, 4th Edition, Sybex, Indianapolis.

4. Hillson D. (ed.) (2016), The Risk Management Handbook: A Practical Guide to Managing the Multiple Dimensions of Risk, Kogan Page, London. 
5. IIBA (2015), A Guide to the Business Analysis Body of Knowledge (BABOK Guide), 3rd Edition, International Institute of Business Analysis, Canada.

6. Jones R. (2009), Zarzadzanie projektami. Sztuka przetrwania, Biznesola, Warszawa.

7. Kałużny S. (2008), Kontrola wewnętrzna. Teoria i praktyka, PWE, Warszawa.

8. Koźmiński A., Piotrowski W. (2002), Zarzadzanie. Teoria i praktyka, Wydawnictwo Naukowe PWN, Warszawa.

9. Lock D. (2009), Podstawy zarządzania projektami, PWE, Warszawa.

10. Mingus N. (2002), Zarzadzanie projektami, Helion, Gliwice

11. Patzak G., Ratty G. (2009), Projekt Management, Linde International, Wien.

12. Pawlak M. (2006), Zarzadzanie projektami, Wydawnictwo Naukowe PWN, Warszawa.

13. PMI (2013), A Guide to the Project Management Body of Knowledge (PMBOK® Guide), 5th Edition, Project Management Institute, Pensylwania.

14. Pritchard C.L. (2015), Risk Management: Concepts and Guidance, 5th Edition, Auerbach Publications, USA.

15. Rowe S.F. (2020), Project Management for Small Projects, 3rd Edition, Berrett-Koehler Publishers, USA.

16. Spałek S. (2004), Krytyczne czynniki sukcesu w zarządzaniu projektami, Wydawnictwo Politechniki Śląskiej, Gliwice.

17. Stabryła A. (2006), Zarzadzanie projektami ekonomicznymi i organizacyjnymi, Wydawnictwo Naukowe PWN, Warszawa.

18. Stabryła A. (2011), Przełomy w teorii zarządzania, „Przegląd Organizacji”, nr 3.

19. Strużyna J. (2010), Rozwój zarządzania zasobami ludzkimi, [w:] Pyka J. (red.), Nowoczesność przemystu i ustug, TNOiK, Katowice.

20. Süß G.M. (2001), Project Management. Efektywne zarządzanie przedsięwzięciami, WEKA, Warszawa.

\section{RISK IN PROJECT MANAGEMENT - CASE STUDY}

Abstract: The aim of the article is to introduce a method of risk identification for a marketing campaign project. The risk breakdown structure is one of the basic documents of risk management, and at the same time often the most frequently used during the whole project. Identifying the most important areas of risk in the project influences risk management throughout the course of the project. Failure to include some important areas may affect the elements of the project triangle, which may have a significant impact on the success of the project. The presented case study shows the areas that were identified in the conducted marketing project in the company.

Keywords: risk, risk breakdown structure, risk management 